\title{
Genus Leporillus.
}

L. apicalis, Gould *.

N. cervinus, Gould.

gouldi, Gould.

longicaudatus, Gould.

C. constructor, $\mathrm{Og}$.
오 53.10 .22 .15 . S. Australia (F. Strange). Gould Coll.

Genus Notomys.

53. 10. 22. 7. $29^{\circ} 6^{\prime}$ S., $141^{\circ} \mathrm{E}$. (Sturt). Gould Coll.

7. 1. 1. 135. W. Australia (J. Gilbert). Tomes Coll.

44. 7. 9. 15. Moore's R., W.A. (J. Gilbert). Gould Coll.

Genus Conilurus.

․ 63. 2.20.1. N.S.W. (G. Caley). Linnean Society.

XLII.-On Specimens of Cephalodiscus densus dredged by the 'Challenger' in 1874 at Kerguelen Island. By W. G. RIDEWOOD.

[Plate XII.]

THe genus Cephalodiscus was founded upon material dredged by the 'Challenger' in January 1876 from Station 311 in the Straits of Magellan; the material was described in 1887 by M'Intosh and Harmer in the Reports of the 'Challenger' Expedition (I2), but preliminary accounts were published in 1882, 1883, and 1885 (Iо, II 8). For many years this material of Cephalodiscus dodecalophus remained the sole representative of the genus, and it was not until 1903 that Andersson (I) announced a rediscovery of Cephalodiscus by the Swedish South-Polar Expedition, and Harmer (5) notified the securing of new species of the genus by the 'Siboga' Expedition. Since that year numerous species have been founded upon material obtained by the 'Siboga' Expedition (6), by Dr. Gilchrist (13), by the 'Discovery' Expedition ( 9,14$)$, by the Swedish South-Polar Expedition (2), by Dr. Schepotieff (I9), by the Second French Antarctic Expedition $(3,4)$, by the Scottish National Antarctic Expedition (7), and by the British Antarctic ('Terra Nova') Expedition (I6).

$\mathrm{Up}$ to the present time sixteen species of Cephalodiscus have been described, but some of the specific names may have to be regarded as synonyms (see $16, p .14$, footnote). A synopsis of all the species of Cephalodiscus at present known

* The Museum received from Gould two specimens of this animal, though he stated that he had only one. It seems, therefore, advisable to nominate the specimen that best tits the description as the lectotype.

Ann. \& Mag. N. Hist. Ser. 9. Vol. viii. 
is given on pages 66-77 of the 'Terra Nova' Report (16), together with a list of all recorded specimens and details of the localities from which they were severally obtained. A key for the ready identification of the various species was published last year in the 'Annals and Magazine of Natural History' (IS).

The first-recorded specimens of Cephalodiscus densus were obtained on the Swedish South-Polar Expedition of 19011903, and were described by Andersson in 1907 (2); other specimens have since been secured on the British Antarctic ('Terra Nova') Expedition of 1910-1913 (i6), and on the Australasian Antaretic Expedition of 1911-1914 (17). It is of particular interest now to be able to record the dredging of material of this species as far back as 1874 - that is to say, two years before the classical material of Cephalodiscus dodecalophus was obtained. While, however, the specimens that form the subject of the present communication must be admitted to be of exceptional interest, by reason of the fact that they were obtained earlier than those of Cephalodiscus dodecalophus, they nevertheless do not constitute the first specimens of Cephalodiscus dredged, for it is almost certain that material of Cephalodiscus nigrescens was obtained on the 'Erebus' and 'Terror' Antarctic Expedition in either 1841 or 1842 (I5).

Previously recorded material of Cephalodiscus densus shows that the species has a wide distribution in the Antaretic seas, specimens having been obtained in Ross Sea by the 'Terra Nova' Expedition, off Giaham Land by the Swedish SouthPolar Expedition, and off Queen Mary Land by the Australasian Antarctic Expedition. It is interesting to be able now to add to these a fourth locality-Kerguelen Island. Should Gravier's species Cephalodiscus anderssoni prove to be the same as Andersson's Cephalodiscus densus, the known distribution of the species is not thereby greatly extended, for the localities from which Gravier's material and Andersson's material were obtained are on the west coast and east coast of Graham Land respectively - see map, pl. vi. in 'Terra Nova' Report (16).

'The material now under consideration is contained in two bottles, and, though all was obtained from the same localityKerguelen Island, Stat. 149, January 1874,- -the subsequent histories of the two parts of it prove to have been different. 'The larger bottle contains seven fragments, four of which might have come from the same colony; these are of a sandygrey colour. The other three pieces are of a rather more rufous tint; they are "dead," with no zooids in the tubes, and the common cœenceial substance between the tubes is 
partly perished, so that the tubes readily separate from one another. Photographs of the two best pieces of the grey material are reproduced in Pl. XII. The largest piece (B) is viewed from the internal or torn surface, $i$.e., the surface by which it was connected with the rest of the colony; on the external or natural surface the tubes are shorter. The upper photograph (A) is a top view of a smaller piece, having shorter tubes.

The material in this, the larger bottle, was in the first instance sent from Edinburgh, where the distribution of the 'Challenger' material took place, to M. S. O. Ridley, to whom was entrusted the writing of the report upon the Monaxonid sponges of the expedition. The original 'Challenger' label, still on the bottle, reads:- "Sponge ; 17 Jan. 1874 ; Royal Sound, Kerguelen Island, 25 fms." Inside the bottle is a parchment label giving the same particulars, although the "Jan." of the date looks like "Jun.," and might be taken to stand for "June"; even in the external label the month of the date looks like "Jane." The "Challenger,' however, was not at Kerguelen Island in June, but in January. 'There is, further, a small parchment label bearing the words "Chall. 159, Royal Sound, Kerguelen, 25 faths." But Station 159 is between Termination Land and Melbourne, with date March 10th, 1874, and depth 2150 fath.- - so that there is evidently here a clerical error, the 159 being a mistake for 149, which is the Kerguelen Island Station. According to the "Summary of Results," part 1, p. 460, the 'Challenger' was off Kerguelen Island from January 9 th to January 29 th, 1874 , and "a great many soundings, dredgings, and trawlings were taken ... in depths varying between 20 and 150 fathoms."

This bottle of material was sent back by Mr. Ridley on June 4th, 1883, marked "Hydroid?." When the part of the "Challenger' Collection known as the "Supplementary Collection" was despatched from Edinburgh to the British Museum (Nat. Hist.) in 1890, the material referred to was registered as 90.4.11.13-i. e., the thirteenth specimen registered on April 11th, 1890. It was still regarded as a kind of Hydrozoan allied to Spongicola fistularis, and remained among the Hydrozoa until it was recognized by Mr. R. Kirkpatrick in February 1919 as a form of Cephalodiscus. Mr. Kirkpatrick reported his discovery to the Director of the Museum, Sir Sidney Harmer, who, in July 1921, was good enough to hand the bottle over to me for a description of the contents.

A few days afterwards, by a strange coincidence, Sir Sidney Harmer submitted to me the second bottle, which had just 28 * 
been received from Prof. W. C. M'Intosh in a collection of specimens taken over from him by the Museum. In the letter that accompanied the collection Prof. M'Intosh writes :- "There are also some annelids, a few of which require working up, a Cephalodiscus? from Kerguelen, and sundry other things." The original "Challenger' label on the bottle bears the words "Kerguelen, 20-60 fms." in ink, and in pencil, in Prof'. M'Intosh's handwriting, "Cephalodiscus? and a curious Polyzoan." The Polyzoan, which is attached to the cœnœcial tubes of the Cephalodiscus, is, I am informed by Sir Sidney Harmer, probably Beania magellanica.

This second bottle has a capacity of 70 c.c. only, and the eight fragments that it contains are all small. Judging from the difference in the records of the depth-20-60 fath. on this bottle, and 25 fath. on the larger bottle-it would seem that the two lots of material did not come up in the same dredging; indeed, it is possible that they were not obtained on the same day, for the 'Challenger' remained off Kerguelen Island for three weeks.

Of the two best pieces in the larger bottle; shown on Pl. XII., the larger (B) measures about $57 \times 44 \times 30 \mathrm{~mm}$. The conøecial tubes vary from 20 to $45 \mathrm{~mm}$. in length, and have a uniform internal diameter of $1.0 \mathrm{~mm}$. The external diameter of the upper parts of the tubes that stand out freely, and are not connected by common cœnœcial substance, is 1.6 or $1.7 \mathrm{~mm}$. Some of the tubes are bulbous at their lower, blind ends, the greatest diameter observed in a bulb being $1.4 \mathrm{~mm}$. The long tubes show a few concavo-convex septa, irregularly disposed, but confined mainly to the lower ends. The extent to which the free part of a tube stands out from the common cœenceial substance varies considerably, mostly within the limits of 10 and $30 \mathrm{~mm}$. Sand-grains occur embedded in the walls of the tubes and in the common cœenœcial substance.

The upper ends of the tubes differ from those of Cephalodiscus densus dredged by the 'Terra Nova' in occasionally showing a lateral lip. The majority of the tubes resemble those represented in the accompanying text-figure, $a$ and $b$, and have the terminal ostium transverse or oblique, without any marked lateral extension; in this respect they resemble the tubes of the 'Terra Nova' material (r6, p. 42, text-fig. 4), although there is a larger proportion of strongly oblique ostia than in the latter. But some of the tubes have a laterally extended ostium (text-fig., c), or a tongue-shaped lateral process $(\mathrm{g})$, or even a funnel-shaped ostium (d). A peculiar feature, represented in the text-figure, e, $\mathrm{f}, \mathrm{g}$, suggests that in 
some of the tubes there has been a cessation and subsequent resumption of growth, for the more terminal parts are paler and more transparent than the rest, with a sharp line of demarcation between the two.

In the 'Terra Nova' material of Cephalodiscus densus some groups of tubes were found to be flanged externally ( 16, p. 41 ,

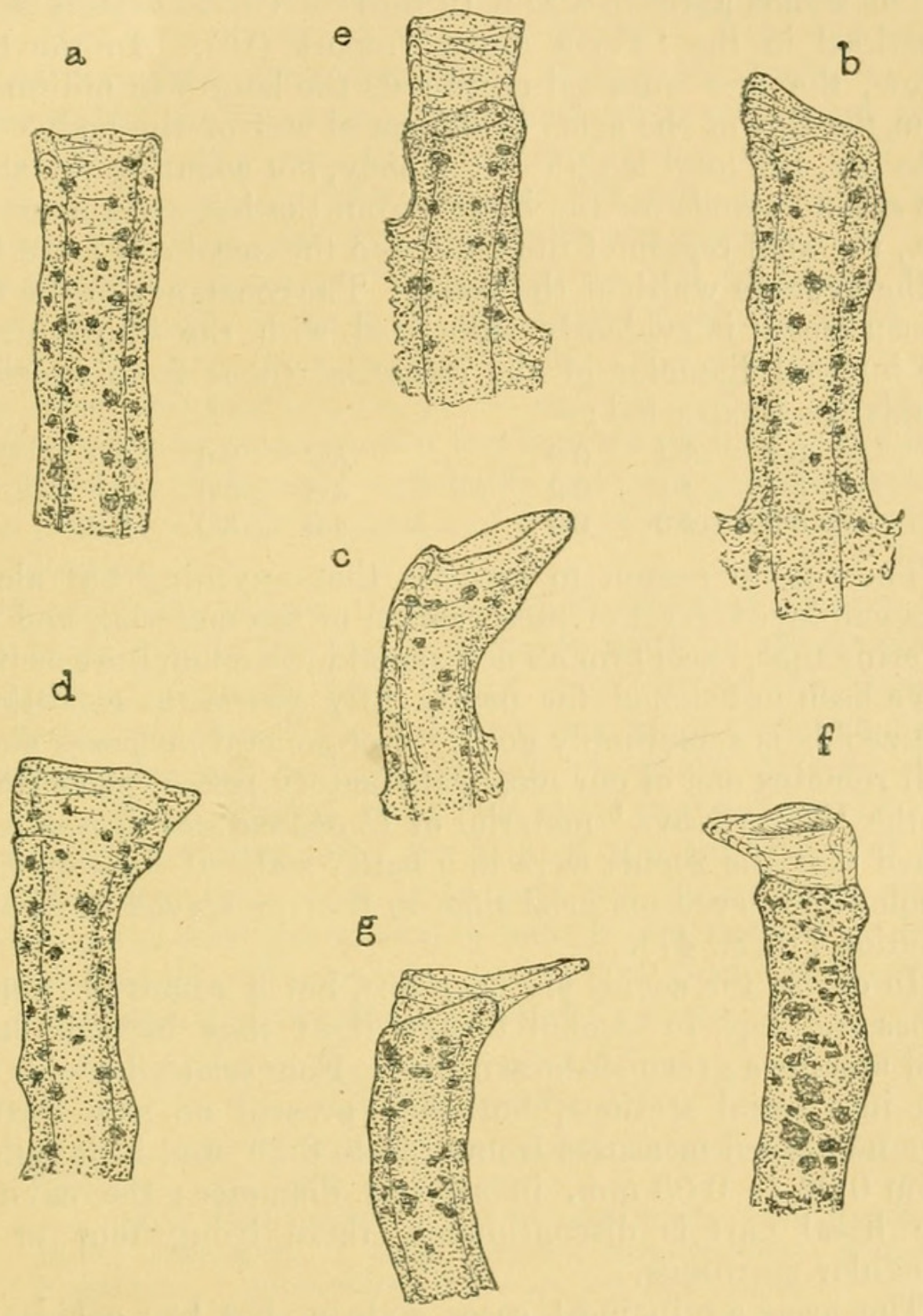

Cephalodiscus densus from Kerguelen Island.

Upper ends of cœenocial tubes, about $\times 6$.

and pl. v. fig. 6), and an explanation of the origin of the flange may be afforded by the occurrence of infundibuliform ostia such as here shown in the text-fig., d. If the growth of such a tube were resumed, and the new part were narrow, like that shown in the text-fig., e, the margin of the funnel would 
then appear as an external flange set at some distance below the upper end of the tube.

The other specimen figured (Pl. XII., A) measures about $28 \times 44 \times 30 \mathrm{~mm}$. None of the tubes are more than $20 \mathrm{~mm}$. in length, and the ostia are almost all transverse, like those shown in the text-fig., a.

The zooids agree in size with those of Cephalodiscus densus described in the 'Terra Nova' report (i6). In the table below, the first numeral represents the length in millimetres from the tips of the arms to the creal end of the body-that is to say, the total length of the body, not eounting the stalk; the second stands for the length from the bases of the arms$i . e$, the anal region of the body-to the cæcal end; the third is the average width of the body. The constancy in the third measurement is evidently associated with the uniformity in the internal diameter of the cœnœcial tubes from which the zooids were extracted:-

$\begin{array}{llllll}5 \cdot 8 & 3 \cdot 4 & 0 \cdot 9 & 5 \cdot 2 & 3 \cdot 6 & 0 \cdot 9 \\ 5 \cdot 7 & 4 \cdot 1 & 0 \cdot 9 & 4 \cdot 8 & 3 \cdot 0 & 0 \cdot 9 \\ 5 \cdot 6 & 4 \cdot 0 & 0 \cdot 9 & 4 \cdot 6 & 3 \cdot 0 & 0 \cdot 9\end{array}$

There is no reason to suppose that anything but alcohol was employed for the preservation of the material, and considering that, except for an occasional inspection, the specimens have been untouched for nearly fifty years, the condition of the zooids is remarkably good. For general purposes alcohol still remains one of our most satisfactory preservative fluids ; in the 'Terra Nova' material of Cephalodiscus densus it was noted that the zooids were in a better state of fixation in the alcohol-preserved material than in that preserved in formalin solution (i 6, p. 47).

In colour the zooids are ochreous, but if removed from the tubes and kept in alcohol in the light they become darker and assume greenish-brown tint. Four selected zooids were cut into serial sections, but they present no new features. The notochord measures from 0.24 to $0.29 \mathrm{~mm}$. in length and from 0.02 to $0.03 \mathrm{~mm}$. in sagittal diameter; the cavity of the basal part is discontinuous, there being four or five irregular partitions.

The arms are in most cases sixteen, but two zooids were found to have seventeen, two eighteen, and one nineteen. In two of the zooids examined one of the marginal arms, next to the edge of the oral lamella, was a diminutive, arrested arm with not more than ten or twelve pairs of tentacles (cf. I6, p. 45, text-fig. 6, H). The tentacles in a fullydeveloped arm consist of forty to fifty pairs.

In the tubes of the piece of colony shown in Pl. XII., B, there occur three kind; of zooids-those with two ovaries, 
those with two testes, and those with an ovary and a testis. The gonads vary in their state of maturity in different zooids. The young ovaries are rather longer and straighter than those figured as C and D in text-fig. 7 of the 'Terra Nova' Report (г6, p. 46), and the pigment-granules around the oviducal aperture are black rather than red. In the material in the smaller bottle, received from Prof. M'Tutosh, all the zooids that were examined had ripe gonads. Free ova occul in this material; they are found among the buds, in the deeper end of the cœnœcial tube, there being not more than one ovum in any one tube. 'The ova are free, and not attached by a stalk; they measure $0.9 \mathrm{~mm}$. in length and $0.6 \mathrm{~mm}$. in width, and the two ends are similar. In two cases where a free ovum was present in the cœnocial tube among the tangle of buds it was found that the zooid inhabiting the tube was hermaphrodite, and the ovary and testis were both ripe ( $c f .16, p .47$, and 17, p. 23 ). It would be interesting to ascertain if a free ovum ever occurs in a tube inhabited by a male zooid-probably.not; the present material is too limited in bulk to permit of a more extended search in this direction.

The greatest number of buds found attached to any one zooid is eighteen; this group includes buds of all stages of development, from the very young stage before the appearance of the red line of the shield up to a large bud with small tentacles appearing on the arms (cf. 16, p. 47 , text-fig. 8 , C and $\mathrm{k}$ ). The youngest buds, however, are not buds of the main zooid, but arise from the side of the extremity of the stalk of a large bud-that is to say, the larger buds begin producing the next generation of buds before separating from the parent zooid. The largest bud of the group of eighteen just mentioned had two small buds of its own.

\section{REFERENCES.}

(r) Andersson, K. A. "Eine Wiederentdeckung von Cephalodiscus." Zool. Anz. xxvi. 1903, pp. 368-369.

(2) - : "Die Pterobranchier der Schwedischen Südpolar-Expedition, 1901-1903." Wiss. Ergebn. Schwedischen SüdpolarExpedition, v. (Stockholm, 1907) pp. 1-122, 8 plates.

(3) Gravinr, C. "Sur une espèce nouvelle de Cephalodiscus (C. anderssoni, nov. sp.) provenant de la Seconde Expédition Antaretique Française." Bull. Mus. Hist. Nat. Paris, 1912, xviii. 3, pp. 146150,2 text-figures.

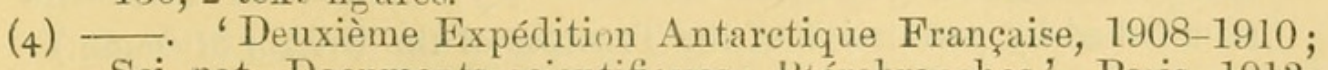
Sci. nat., Documents scientifiques; Ptérobranches.' Paris, 1913, pp. 71-86, 5 text-figures.

(5) Harmer, S. F. "On new Localities for Cephalodiscus." Zool. Anz. xxvi. 1903, pp. 593-594.

(6) - "The Pterobranchia of the 'Siboga' Expedition, with an 
Account of other Species." . Résultats des Explorations entreprises aux Indes Néerlandaises Orientales en 1899-1900 à bord du 'Siboga,' livr. xxii. monogr. 26 bis, Leiden, 1905, pp. 132, 14 plates and 2 text-figures.

(7) Harmer, S. F., and Ridewood, W. G. "The Pterobranchia of the Scottish National Antaretic Expedition, 1902-1904." Trans. Roy. Soc. Edinb. xlix. 3, 7, 1913, pp. 531-565, 2 plates and 5 textfigures.

(8) Lankester, E. R. Article "Polyzoa," Encycl. Britann. ed. 9, xix. 1885, pp. 429-441. (Contains the first published figures of Cephalodiscus, made from drawings supplied by Prof. M'Intosh.)

(9) - "On a new Species of Cephalodiscus (C. nigrescens) from the Antarctic Ocean." Proc. Roy. Soc. London, 1905, lxxvi. B, pp. 400-402, 1 plate.

(г) M'Intosh, W. C. "Preliminary Notice of Cephalodiscus, a new Type allied to Prof. Allman's Rhabdopleura, dredged in H.M.S. 'Challenger.'" Ann. \& Mag. Nat. Hist. 15) x. 1882, pp. 337-348.

( I I ) - "Preliminary Note on Cephalodiscus, a new Form allied to Prof. Allman's Rhabdopleura." Rep. Brit. Assoc. (Southampton, 1882) 1883, pp. 596-597.

(12) - " "Report on Cephalodiscus dodecalophus." 'Challenger' Reports, Zool. xx. 62, 1887, with an Appendix by S. F. Harmer, pp. 48,7 plates and 6 text-figures.

(13) Rinewood, W. G. "A new Species of Cephalodiscus (C.gilchristi) from the Cape Seas." Marine Investigations, South Africa, iv. (Cape Town, 1906) pp. 173-192, 3 plates and 5 text-figures.

(14) - " "Pterobranchia ; Cephalodiscus." National Antaretic Expedition ['Discovery'], Nat. Hist. ii. (London, Brit. Mus.), 1907, pp. 1-67, 7 plates and 17 text-figures.

(15) . "On Specimens of Cephalodiscus nigrescens supposed to have been dredged in 1841 or 1842." Ann. \& Mag. Nat. Hist. (8) x. 1912, pp. 550-555, 1 text-figure.

(г6) - British Antaretic ('Terra Nova') Expedition, 1910; Nat. Hist. Reports, Zool. iv. 2, Cephalodiscus (London, Brit. Mus.), 1918, pp. 11-82, 5 plates and a map, and 12 text-figures.

(17) - Australasian Antarctic Expedition, 1911-1914, Sci. Reports, ser. C, iii. 2, "The Pterobranchia," 1918 (Sydney), pp. 25, 2 plates and 3 text-figures.

(18) - "A Key for the Ready Identification of the Species of Cephalodiscus." Ann. \& Mag. Nat. Hist. (9) v. 1920, pp. 407-410.

(x9) Schepotrefr, A. "Die Pterobranchier des Indischen Ozeans." Zool. Jahrb., Abth. Syst. xxviii. 4, 1909, pp. 429-448, 2 plates.

\section{EXPLANATION OF PLATE XII.}

Photographs, of the natural size, of two specimens of Cephalodiscus densus, Andersson, dredged by the 'Challenger' in Royal Sound, Kerguelen Island, Jan. 17th, 1874, from a depth of 25 fath. A, top view; $B$, side view.

\section{XLIII.-The Jerboa of Muscat. By Oldfield Thomas.}

(Published by permission of the Trustees of the British Museum.) W Hile determining an example of Jaculus loftusi obtained near Baghdad by Major Cheesman, my attention has been drawn to the examples from Muscat presented by Dr. Jayakar and hitherto referred to the same species. But with six 


\section{$2 \mathrm{BHL}$ Biodiversity Heritage Library}

Ridewood, W C. 1921. "XLII.-On specimens of Cephalodiscus densus dredged by the 'Challenger' in 1874 at Kerguclen Island." The Annals and magazine of natural history; zoology, botany, and geology 8, 433-440.

https://doi.org/10.1080/00222932108632603.

View This Item Online: $\underline{\text { https://www.biodiversitylibrary.org/item/84523 }}$

DOI: https://doi.org/10.1080/00222932108632603

Permalink: https://www.biodiversitylibrary.org/partpdf/63792

\section{Holding Institution}

Smithsonian Libraries

\section{Sponsored by}

Smithsonian

\section{Copyright \& Reuse}

Copyright Status: Public domain. The BHL considers that this work is no longer under copyright protection.

This document was created from content at the Biodiversity Heritage Library, the world's largest open access digital library for biodiversity literature and archives. Visit BHL at https://www.biodiversitylibrary.org. 